Meta

Journal des traducteurs

Translators' Journal

\title{
Discovering Australia Through Fiction: French Translators as Aventuriers
}

\section{Helen Frank}

Volume 51, numéro 3, septembre 2006

URI : https://id.erudit.org/iderudit/013554ar

DOI : https://doi.org/10.7202/013554ar

Aller au sommaire du numéro

Éditeur(s)

Les Presses de l'Université de Montréal

ISSN

0026-0452 (imprimé)

1492-1421 (numérique)

Découvrir la revue

Citer cet article

Frank, H. (2006). Discovering Australia Through Fiction: French Translators as Aventuriers. Meta, 51(3), 482-503. https://doi.org/10.7202/013554ar
Résumé de l'article

La traduction en français des référents de l'Australie et d'« australianité » dans la fiction rend nécessaire une variété considérable de tendances de traduction et de choix interprétatifs. Cette étude se concentre sur des traductions françaises des passages et des textes de présentation choisis de l'ensemble australien de fiction en Australie régionale pour déterminer comment des référents australiens de la flore, de la faune, du paysage et des gens sont traduits et interprétés dans un système culturel en dehors du monde d'expression anglaise. Favorisant les lecteurs dans la culture cible, les traducteurs tendent à recourir aux stratégies et aux normes de traduction qui soulignent l'orientation du lecteur et la compréhension du texte. Il existe néanmoins l'évidence de l'appropriation du texte et d'une manipulation systématique des référents australiens qui dépasse les normes de traduction et qui reflète certaines préoccupations françaises. De telles manipulations et appropriations proviennent d'un désir de créer et stimuler des suppositions culture-spécifiques au sujet de l'Australie qui soient conformes aux préoccupations françaises du colonialisme, de l'exotisme, de l'exploration et de l'aventure.
Ce document est protégé par la loi sur le droit d'auteur. L'utilisation des services d'Érudit (y compris la reproduction) est assujettie à sa politique d'utilisation que vous pouvez consulter en ligne.

https://apropos.erudit.org/fr/usagers/politique-dutilisation/ 


\title{
Discovering Australia Through Fiction: French Translators as Aventuriers
}

\author{
HELEN FRANK \\ University of Melbourne, Melbourne, Australia \\ htf@unimelb.edu.au
}

\begin{abstract}
RÉSUMÉ
La traduction en français des référents de l'Australie et d'«australianité » dans la fiction rend nécessaire une variété considérable de tendances de traduction et de choix interprétatifs. Cette étude se concentre sur des traductions françaises des passages et des textes de présentation choisis de l'ensemble australien de fiction en Australie régionale pour déterminer comment des référents australiens de la flore, de la faune, du paysage et des gens sont traduits et interprétés dans un système culturel en dehors du monde d'expression anglaise. Favorisant les lecteurs dans la culture cible, les traducteurs tendent à recourir aux stratégies et aux normes de traduction qui soulignent l'orientation du lecteur et la compréhension du texte. Il existe néanmoins l'évidence de l'appropriation du texte et d'une manipulation systématique des référents australiens qui dépasse les normes de traduction et qui reflète certaines préoccupations françaises. De telles manipulations et appropriations proviennent d'un désir de créer et stimuler des suppositions culturespécifiques au sujet de l'Australie qui soient conformes aux préoccupations françaises du colonialisme, de l'exotisme, de l'exploration et de l'aventure.
\end{abstract}

\begin{abstract}
The translation into French of referents of Australia and Australianness in fiction necessitates a considerable variety of translational tendencies and interpretive choices. This study focuses on French translations of selected passages and blurbs from Australian fiction set in regional Australia to determine how referents of Australian flora, fauna, landscape and people are translated and interpreted in a non-English speaking cultural system. Guided by concerns for the target readers' understanding of the text, French translators employ normative strategies and adaptive procedures common to translation to enhance reader orientation. There is, nonetheless, evidence of culture-specific appropriation of the text and systematic manipulation of Australian referents that goes beyond normative solutions. Such appropriation and manipulation stem from a desire to create and foster culture-specific suppositions about Australia consistent with French preoccupations with colonialism, the exotic, exploration and adventure.
\end{abstract}

\section{MOTS-CLÉS/KEYWORDS}

Australia, Australian fiction, children's literature, French translation, culture

\section{Introduction}

To translate in France and into French is to place oneself within a particular cultural tradition, whereby the meeting of another culture in fiction involves degrees of compromise of the linguistic, social and cultural codes of two languages and cultures. In selecting Australian fiction for translation, French publishers are taking onboard a primarily Anglo-Celtic culture situated, from a Eurocentric perspective, at the other end of the world. In the negotiation of Australian narratives, French translators make 
choices consistent with a concern for readers in France and with "[...] a sensibility that interprets references of Australia from the perspective of French preoccupations" (Riemer 2003: 58). Translators manipulate and adapt the culture-specific information for a new audience in the interests of comprehensibility and acceptability. The potential, and in some cases the necessity, for the interpretation and re-interpretation of culturally specific elements of the original text represents an important variable in the translation process. Arguably, choices by translators reflect literary, philosophical and cultural preoccupations expressing in French terms the world-view of the Australian text.

The aim of all good translation is to render the text intelligible to readers of a different cultural background while conveying the distinctiveness of the original perspective. The present work highlights the variety of norms and strategies of translation in representing Australian cultural identity in French translation. To illustrate this variety, examples of extracts and synopses of twentieth century Australian fiction with regional settings have been selected. The titles for young readers derive from a defined corpus of twentieth century Australian works for children in French translation (Frank 2003). The examples from adult texts emanate from a comprehensive survey by the author of twentieth century Australian fiction for adults in French translation. In total, over 60 works with regional settings have been consulted, with the French translations spanning a period from the 1950s to the early 2000s. Given the time span, we would expect a change of norms in the strategies adopted by translators as they rewrite situations consistent with ideologies and translating purposes. As Oittinen (2000: 142) states, "[...] translations are always created in unique situations that influence translators' ways of reading and understanding texts." The use of the term "translator" implies all agents involved in the publishing trade (Toury 1995), and the examples presented here are representative of the most common translating strategies, norms and tendencies in the Australian-French encounter through fiction.

The research topic addresses two major issues in the translation of literature. The first issue concerns the translator's prioritization of the accessibility of the text for the prospective reader in another culture. Translators are reading for a specific audience for whom they take liberties in the process of translation. These liberties take the form of adaptations that occur precisely because translators make judgments of the content of texts based on what they perceive to be appropriate or inappropriate in the target culture. Translation as interpretation and adaptation means that translators generally aim to make the content more readable, accessible and transparent through a range of normative choices, strategies, tendencies and simple intuition. Although often comprising the literariness of the text, adaptations generally reflect a paternalistic didacticism that may be cultural, technical or moral.

The second issue concerns national preoccupations and cultural presuppositions. Throughout history, French preoccupations with colonialism, the exotic, exploration and adventure have exerted considerable influence on French national culture and on the French perception of other cultures. In the case of literary works, these preoccupations have the potential to influence the translational decisions in response to the offer of information provided in the source text. At the same time, awareness of the cultural expectations of the prospective audience, described by Nord (1997: 62) as the "culture-specific knowledge presuppositions," will inevitably influence the transmission of Australian cultural specificity in fiction translated into French. The 
influence of all forms of media and their recourse to clichéd labels and stereotypes in constructing Australia and "Australianness" also influence French translators in their portrayal of Australian culture for target readers.

As a frequent commentator on Australian culture and literature from a French perspective, Xavier Pons ${ }^{1}$ challenges the stereotype of Australia as Aborigines, kangaroos, surf and large spaces in his recent monograph L'Australie, entre Occident et Orient (2000), and attempts to defend an image of contemporary Australia as an advanced, pluralistic, democratic society. The dossier de presse for his monograph includes the following extract:

L'Australie se réduit-elle à ses aborigènes, ses kangourous, son surf et ses grands espaces? Certes non. Si, aux antipodes de la France, elle reste synonyme de dépaysement et d'aventure, sa réalité est bien autre chose. Pays de haute technologie, elle est dotée d'une économie dynamique qui lui assure un niveau de vie élevé.

However, research by Macdonald (1996) concludes that French translations mythologize Australia in a manner consistent with pre-conceived notions, constructing Australia as the bush, the desert, or the "last" place on earth. Similarly, the French critical reception of twentieth century Australian cinema detects "[...] the seemingly all-pervasive exoticist mythologizing of Australia as a European antipodes” (McGregor 2004: 169). One significant aspect on which these critics agree is that Australia remains a fascinating place in the European imagination and invites perpetual "discovery."

One means of "discovering" Australian culture is through the literary selection process, whereby French publishers select fiction deemed worthy of translation for a range of ages of readership. One assumption for the selection of Australian material is that French publishers are interested in Australian settings and perspectives. While the selection process represents the overall objective of publishers to select specific genres, authors, themes or settings, the translation process reflects most succinctly the presuppositions and preoccupations of the target culture at the level of the narrative. The analysis of extracts and synopses from Australian works not only reveals the range of norms and strategies of translation provided by individual translators but also the range of French images of Australia.

French interests in the "other" and the capacity of the French to impose their "Frenchness" have been noted in critical works on historical and literary French narratives. On the French preoccupation with colonialism, Betts (1978) notes the national fixation with colonial expansion and the French Overseas Empire, and Prochaska (1990) outlines the French colonization of Algeria in terms of the transfer of cultural patterns to a different social and historical context in the process of making Algeria "French." The French preoccupation with discovery and exploration is addressed by Piquet (2000) in an analysis of French exploration and imperialist designs in the Pacific in the late eighteenth and early nineteenth centuries. Piquet's research reinforces French interests in the Antipodes and its exoticism, interests also described by Riemer (2003) as an expression of the infatuation in French culture with the nobility of indigenous populations of exotic lands and islands. Jackson (2003) notes the French fascination with Africa and primitivism in his study of the spread of jazz in France after World War I. The process of appropriating and synthesizing elements of other cultures is a consistent theme in French cultural history, and the analysis by 
Nettelbeck (2004) of the French response to and appropriation of the freedom and improvisation of American jazz music underscores the capacity of the French to take something from outside and make it part of their own culture.

In view of the "in-betweenness" inherent in the translation of cultures (Bartolini 2003: 91), the following sections discuss the images and concepts in the meeting of Australian and French cultures and frames of reference. At times selected passages present considerable difficulties for a translator and misunderstanding can lead to misrepresentation of the source culture. However, when translators focus on their target readers and use target culture norms and conventions, they are attempting to produce a text that makes sense to target-culture receivers. Distilled through a filter of images and presuppositions, the translation of Australia inevitably leads to narratives that assume a distinctly French "look."

\section{Australian Flora, Fauna and Landscape}

\section{Retaining Australian Cultural Specificity}

The portrayal of Australian exoticism in fiction represents both positive and negative referents. While positive exoticism is evident in the portrayal of referents that reflect attractive or interesting features of Australian flora, fauna, history and people, negative exoticism comprises referents that portray objective realities about Australia that are often regarded as too "real" for certain ages of reader in other cultures and thus unattractive or unsuitable. Content that is ideologically, socially and culturally different (strange, peculiar, unfamiliar) creates a tension for the translator who must decide on the degree of acceptability and translate accordingly. At times translational decisions may negate Australian cultural specificity in the interests of removing or toning down material perceived as inappropriate for French readers of varying ages.

The most marked form of the specificity of Australia is undoubtedly its landscape, and there is a tendency for Australian cultural identity in general to be equated with, and portrayed as, Australian nature. It is inevitable therefore that translators of Australian fiction with regional settings must negotiate a substantial Australian content in the form of referents of the Australian landscape, flora and fauna. In the following example, the translator has stayed as close to the original text as possible, retaining all referents and only intensifying one moment in the passage. ${ }^{2}$

\section{James Vance Marshall. The Children (1959) = Dans le grand désert (1968), Patrick Reumaux (Tr.)}

They examined the tawny leopard-trees, the sapless mellowbane, the humble-bushes with their frightened collapsing leaves, and the blood-woods with their overflowing crimson sap. They skirted the kurrajongs and the bottlebrushes and the eucalyptus; then they came to a group of trees of another, rarer kind: graceful, symmetrical trees, covered with thick silver foliage and - miracle of miracles - with multicoloured globules of fruit. (p. 23)

Avec quelle avidité n'examinèrent-ils pas les arbres léopards au pelage fauve, les buissons de sensitives aux feuilles tremblantes et les eucalyptus rouges à l'abondante sève sanglante. Ils contournèrent les arbres à corde et les banksias, aux curieuses fleurs en goupillon, et les eucalyptus, atteignirent ensuite un bouquet d'arbres d'espèce plus rare, aux jolies formes symétriques, couverts d'un épais feuillage argenté et - miracle entre les miracles! - de baies multicolores. (p. 29) 
In the process of translation, translators interpret texts for different purposes and audiences, and attempt to help target readers to recognize the text world as being consistent with their own reality. Here the translator has translated both the Australianness and the poetic rhythm of the passage, retaining the fluency of expression and preserving the phonic and prosodic elements that contribute so forcefully to the sound of the text. However, in some cases a literal translation of the cultural references is impossible or inappropriate and the translation purpose may be shifted toward the reader's presumed interest in other cultures and the text world will be explained through recourse to footnotes.

Footnotes are the extreme example of retention of the unique and marked features of the source text, where the cultural referents are deemed so unfamiliar to the reader that the translator keeps the original term and provides definitions. Translators use footnotes as a translational strategy for cultural divergence in the belief that learning new aspects of another culture provides an enriching experience. Footnotes may also reinforce cultural stereotypes and myths in the perception of the otherness of the Australian landscape and its inhabitants. As an alternative translation strategy for cultural divergence, definitions and clarifications can be embedded in the text to minimize distraction from the narrative.

A sample of footnotes from our corpus of French translations shows the referents with the greatest number of footnotes as the wombat (phascolome), platypus (platypus ou ornithorynque), wallaby (wallaby), Tasmanian tiger (loup thylacine), Tasmania (Tasmanie), bushranger (un bushranger) and the bush (le bush/la brousse), without doubt the most culturally-bound term overall. Amongst the Australian referents judged by translators to be marked by their opacity to French readers are also the frogmouth (bouche-de grenouille ou podarge), thrush shrike (langrayen), bandicoot (péramèle), gang-gang cockatoos (cacatoès gang-gang), Tasmanian devil (diable de Tasmanie), dingo (dingo), kookaburra (koukabourra), sassafras tree (sassafras), grass trees (xanthorrhées), gum trees (arbres à cidres), banksias (banksias), King William Pine (Pin King William), Huon pine (pin huon), creek (creek) and football (football australien).

The proliferation of references to flora and fauna in these examples suggests a strong interest in Australianness that is deemed worthy of retention and explanation by the translators as best they can. Although the accuracy of some footnotes may be strongly contested, the definitions provided by translators frequently refer the reader to a known referent to help in understanding the unknown, such as "un phascolome" = like a kangaroo, "un péramèle" = like an opossum, "un wombat" = like a small bear, or in assigning referents to a general geographical area, such as "cacatoès gang-gang" $=$ Australian birds. In these examples, translators have adopted processes well known in the translation of literature, whereby relating the unknown to the known, and supplying the general for the specific minimize the foreignness of the text. On occasions translated footnotes contain technical language that transmits a didactic tone and tends to increase the distance between the narrative voice and the reader, such as "L'iridosmine est une substance d'un blanc d'étain, ou d'un gris de plomb, essentiellement composée d'iridium et d'osmium" (Chauncy 1968: 13), and "un pommier australien est un arbre mystacé du genre Angophora" (Franklin 1996: 58). However, the general strategy of these translators to explain the foreign referents to readers in the target culture reinforces the desire to bring the text closer to the reader's experience. 
The translator's decision to retain as much as possible of the source work is illustrated in the following passage from a work by Mary Patchett, one of the most translated Australian authors. The fact that the French translator intended the work for older readers, as did the author of the original work, may have influenced the translator's decision to translate adequately.

Mary Patchett. In a wilderness (1962) = Mirri chien sauvage (1965), Christiane Blanc (Tr.)

One morning, after an unproductive night, his attention was arrested by something in the distance that looked like a moving burr, about nine or ten inches long. It moved towards a patch of soft ground, its eyes were bright, and it had a peculiar, handle-like nose stretched out in front of it. Remembering his experience with the pugnacious goanna, Mirri followed this new oddity from a respectful distance. (p. 37)

Certain matin, après une nuit de chasse malchanceuse, son attention fut retenue par une chose qui se présentait, de loin, comme une capsule épineuse, mouvante, longue de 20 à 25 centimètres, qui se déplaçait vers un morceau de terrain mou. Cette drôle de créature aux yeux brillants était munie d'un museau en forme de trompe qui s'étirait devant lui. Mirri se souvenant de sa malheureuse expérience avec l'iguane batailleur, suivit à pas de loup et à distance respectueuse cette nouvelle bizarrerie de la nature. (p. 60/1)

The normative technique of drawing on something known to readers in order to help them understand the unknown is evident in the use of "munie d'un museau en forme de trompe" for "handle-like," "son bec corné" for "its snout," and "une capsule épineuse" for "a moving burr." The tendency to emphasize and increase exoticism is seen in the translation of references to the echidna, such as "cette nouvelle bizarrerie de la nature" for "this new oddity," and "cette drôle de créature." This passage connotes the sense of wonder in the discovery of new creatures, a common theme in the history of French scientific voyages of discovery in the nineteenth century. In exploring exotic foreign lands in general, and the colonies of the new French empire specifically, scientists and naturalists provided detailed inventories and artwork depicting plants, animals, tools and indigenous inhabitants (Osborne 1994). In a similar literary voyage, the French translator here has taken a keen interest in the exotic creature of the Australian landscape, and has identified the echidna as worthy of detailed examination.

Whereas this first set of examples has illustrated translation strategies of retention and enhancement of the cultural specificity of the text, the following section concentrates on translations that choose to minimize, adapt or delete Australian cultural specificity. These contrasting choices by translators are evidence of the coexistence of several norms of translation. Translations interested in Australianness as landscape may at the same time reflect a lack of curiosity concerning local aspects of life in Australia.

\section{Suppressing Australian Cultural Specificity}

The reaction of translators to local specificity is demonstrated in Colin Thiele's River Murray Mary (1979) = Mary, la rivière et le serpent (1985), an example of the text writing itself through the landscape. This novel is a local regional story strongly anchored in place and time, with detailed descriptions of the local world against a 
background of the general Australian landscape. There is an extreme concern by the translator with typicality, locality and point-of-view, with divergence occurring only when the English becomes too local. Where the original text describes nature or the landscape, the translator uses the same metaphors in an attempt to stay as close as possible to the original text. However, in instances where the local world is described in minute detail, the translation downplays the concrete language and imposes a general structure of intelligibility on what is local or rooted regionally. For example, the vocabulary of the local world depicting harvest time and fruit picking is suppressed in the translation. In this work, the primary interest of the translator is the landscape, whereby Australianness is equated with a paradise or a Garden of Eden. The suppression of the human world, the world of work, is in contrast to the exploitation of the natural world, the world of exoticism.

References to the Australian landscape can also be present in the form of metaphors and similes that are highlighted or deleted in translation. In the following set of examples, the translator has consistently deleted the Australian referent:

Morris Gleitzman. Sticky Beak (1993) = Le bébé de papa compte plus que moi (1998), Shaïne Cassim (Tr.)

I glowed even more and Ayers Rock suddenly melted away and all that was left was a wonderful feeling that everything was going to be OK forever and ever. (p. 61)

J'ai rayonné de bonheur à l'intérieur. (p. 112)

Ayers Rock hit me in the guts ... Suddenly Ayers Rock wasn't in my guts anymore. (p. 96)

Un énorme trou a creusé mon ventre... Soudain le trou n'était plus dans mon ventre. (p. 181)

Ayers Rock is considered to be one of the three great icons of Australia, the other two being the Sydney Harbour Bridge and the Opera House. These three icons of Australia abound in tourist brochures and are instantly recognizable by many people throughout the world. For this very reason, it is all the more intriguing that the translator deleted such a marked feature of Australianness. In addition it is worth noting that the translation "trou" - a hole or cavity implying emptiness - is the negation of the very large cultural and geographical object, Ayers Rock. In examples from Gleitzman, translating the specificity of Queensland has resulted in a variety of geographically loose and neutral references.

Morris Gleitzman. Worry Warts (1991) = Mes parents sont de mauvais poil (1998), Shaïne Cassim (Tr.)

'The trouble with North Queensland,' said Mrs Newman, 'is that your feet swell up.' (p. 3)

- Le problème avec la Baie de l'Orchidée, c'est que les pieds enflent facilement. (p. 10)

'It'll be a surprise alright,' said Tracy, 'when they've got the only green car with yellow stripes in the whole of Far North Queensland.' (p. 10)

- Ah ça, c'est sûr! Quand ils vont voir qu'ils sont les seuls à avoir une voiture verte avec des bandes jaunes dans cette partie de l'Australie. (p. 21)

Then the crowd broke into cheers and applause and slapped Curly on the back and told him he had the only [multicolored] general store in Central Queensland that was not only a major tourist attraction but could also be used by aircraft for navigating in heavy fog. (p. 86) 
Certains vinrent féliciter Beau Bouclé: il était le seul du pays à posséder un magasin tellement coloré qu'il devenait un repère dont les avions pourraient se servir pour s'orienter par temps de brouillard. (p. 154)

References to Far North Queensland and Central Queensland undergo conversion as specific places and are replaced by a general "anywhere" ("dans cette partie de l'Australie") or "everywhere" ("du pays"), and North Queensland is replaced with a specific place, "La Baie de l'Orchidée."

Apart from examples of Australianness as flora and fauna, we also have people whose relationship with the landscape bestows connotations of Australianness, such as swagmen. In Brinsmead's work, it comes as no surprise that the absence of the concept of a swagman in France results in a translation that tries to convey the more general notion of someone who has no permanent home. The description of a swagman in Fennimore's work receives a similar translation.

Hesba Brinsmead. Once There Was a Swagman (1979) = Un jour, un vagabond (1986), Anne-Marie Chapouton (Tr.)

Many a swagman had unrolled his bluey in the bark hut of Wangerra. (p. 11)

Plus d'un vagabond avait déroulé sa literie dans la cabane d'écorce de Wanguerra. (p. 35)

Stephen Fennimore. Bush Holiday (1948) = Vacances en Australie (1957), Edith Vincent (Tr.)

Presently they passed a man trudging along the side of the road. His clothes were old and torn and he wore a battered hat. Slung on his back was a big roll done up in a blue blanket, from which hung a blackened tin can and a worn canvas bag. He didn't seem to notice the weight on his shoulders, but plodded on. His face was round and cheerful above a fringe of whiskers, and he gave them a nod and a grin and a half-military kind of salute as they clattered by. "Swagman," said Mr. Macleod. "Swag on back, tucker-bag, billy-can.” (p. 24)

Puis ils dépassèrent un homme qui cheminait au bord de la route. Ses vêtements étaient en lambeaux et un vieux chapeau tout racorni l'abritait du soleil. Sans paraître se soucier du poids, il portait sur l'épaule un gros ballot roulé dans une couverture. Son visage, orné d'une paire de moustaches, était gai et jovial. Il leur fit un signe amical au passage. - Chemineau, dit M. Macleod. Sac au dos, avec la bouffe, la gamelle et le reste. (p. 24)

The specificity of the "swag," "tucker-bag" and "billy-can" are difficult to convey in French, so the translator's choice of a normative solution permits the description of the referents in more general terms. The use of these neutral terms explains why there is deletion from the early part of the passage of the tin can and canvas bag, for otherwise there would be needless repetition of the general items. The tendency towards the choice of neutral terms in translation continues with the description of the swaggie's specific type of salute, where "a half-military kind of salute" becomes "un signe amical." As we have seen in earlier examples, the equation of Australia with heat is evident in the addition of "l'abritait du soleil" to explain the reason for wearing a hat. 


\section{Constructs, Models and Cultural Borrowings}

In a similar way to the notion of a swagman, the notions of a settler and an outlaw cause problems for French translators as they carry connotations of frontiers and the wild west, and can lead to translations that reveal constructs borrowed from American history. This is most succinctly portrayed in the Australian and French blurbs from Peter Carey's Booker Prize winning title for adults featuring the Australian legendary figure, the bushranger Ned Kelly. This example also reinforces the influence of French preoccupations with exploration and with individuals who epitomize the aventurier model.

Peter Carey. True History of the Kelly Gang (2000) = Véritable histoire du Gang Kelly (2003), Elisabeth Peellaert (Tr.)

"[...] Here is a classic outlaw tale, made alive by the skill of a great novelist."

«[...] Dans ce western australien tour à tour poignant et comique, écrit dans une langue savoureuse qui rappelle le Mark Twain de Huckleberry Finn, Peter Carey donne une vibrante humanité à Ned Kelly, qui rejoint ici Robin des Bois et Billy Kid au panthéon des hors-la-loi au grand cœur».

This example from Carey highlights another choice in the negotiation of Australianness whereby translators find a normative solution by reverting to a familiar model in literature. Common models of child protagonists in children's fiction are the self-sufficient or rebellious individual, the sick child, the orphan, the lost child, the spoilt child and so on, such as Tom Sawyer, Pippi Longstocking, Huckleberry Finn, Oliver Twist, Little Lord Fauntleroy, le petit Nicolas, Alice in Wonderland, Robinson Crusoe, Robin Hood, Cinderella and Peter Pan. Australian authors have exploited characters consistent with such models, such as the central character of Mary in River Murray Mary who is portrayed as a figure of nature and as a female Tom Sawyer; Bett Bett, the young Australian Aboriginal in The Little Black Princess, is modeled on the noble savage prototype; Spit MacPhee in The True Story of Spit MacPhee exhibits traits common to Lindgren's model of the rebellious and self-sufficient Pippi Longstocking; Dot characterizes the lost child model in Dot and the Kangaroo as she wanders through the Australian bush; miniature-sized Miss Nancy Clancy in Ned Kelly and the City of the Bees resembles Alice from Alice in Wonderland not only in size, but also in her penchant for speaking in riddles and rhymes; and the lonely wanderer, Storm Boy, is an archetypal Huck Finn.

Translators are equally aware of these models and will revert not only to the common model, but also on occasions to the French version of such models. For example, both Blinky Bill, the independent and roguish koala of the Australian outback, and Dusting, the hilarious school delinquent in Adventures with My Worst Best Friend, exhibit traits in translation reminiscent of France's beloved rascal, le petit Nicolas. The central characters in the McGowan and Simon Black series take on heightened characteristics of French aventuriers who were famous for their sustained series of explorations to the Pacific region, such as Bougainville, La Pérouse, D'Entrecasteaux and Baudin (Hunt and Carter 1999). As illustrated in the Carey example, modeling is not confined to the realm of children's books; a range of models such as James Bond, Florence Nightingale, Sir Arthur, Frankenstein, Robin Hood, Sherlock Holmes and even Barbie also find their doubles in fiction for adults in various languages and in translation. 
Just as common models exert influence on French translations, so do cultural borrowings. Constructs borrowed from American history in the example from Carey are representative of a consistent process in the translation of Australian works whereby Australia is described via American culture. Even when translating simple television shows, there is evidence to suggest that French children are more familiar with popular culture in the United States than in Australia, as rough equivalents are substituted via American culture.

Morris Gleitzman. Worry Warts (1991) = Mes parents sont de mauvais poil (1998), Shaïne Cassim (Tr.)

Keith lay there through the rest of Play School, all of Danger Mouse, and some of Gumby. (p. 46)

Il était resté étendu le temps qu'aient fini de défiler à la télévision Mickey, Tom et Jerry et un troisième dessin animé dont il avait oublié le nom. (p. 52)

The perception of Australia as a younger version of America draws from traditions of nineteenth-century dime novels of adventure and frontier narratives, and the genre of the American western in literature and in film has been noted by theorists as instrumental in the building of nationhood and culture (Monaghan 2003). Equally crucial to the development of the Australian character, the concept of the landscape as a frontier (Ward 1958) invites speculation on the influence of American pioneering traditions in the mythologizing and propagation of fantasies about Australia by French translators. In the reading of Australian rural fiction as derivative of the American western genre, French translators stress themes of domination of the landscape, mapping the void, ownership and power. These themes are illustrated in detail in the section discussing heightened images of Australia in translation. The mission civilisatrice of French colonialism may well account for the significant number of selections featuring colonial settings and recall earlier French literature of adventure set in colonial Australia, such as the works of Jules Verne. ${ }^{3}$ The lack of a literary genre of heroic colonial novels in France may have contributed to a greater interest in the far away and exotic, allowing a young and relatively unknown Australia to be discovered by France in fiction.

Constructs borrowed from French history also influence the translator's use of discourse-specific language. In the following example, the translator has understood the tone of mock seriousness in the original text and has translated it competently as the discourse of Republican citizenship.

Thomas Keneally. Ned Kelly and the City of the Bees $(1978)=$ La cité des abeilles (1981), Rose-Marie Vassallo (Tr.)

In a space inside the front door, a group of drones was meeting in a bunch. They were husky fellows and I noticed their large eyes took up almost all their head. One of them stood apart from the others and seemed to be making a speech. When he saw us he began to speak in English, as if to impress us.

"And, gentlemen, I would like to draw your attention to our two young visitors from the outside world. I would like their presence to ask, are our so-called sisters, the socalled workers, going to throw us out of the hive again this autumn? Are they going to do it in front of the eyes of two strangers from the outside world, two such persons as those climbing on the comb there? Are they really going to shock those young eyes by hurling us, sad, solitary, sopping and starving, out into a forest full of enemies? When 
we try to return, are they going to hurl us once more away from the door and tell us there is not room or food for us? Does the race of humans treat each other like that? Do they behave like that in Martin's Corner or Rick the Frontier Scout? I say that we belong here as much as the workers, as much even as the Queen!"

This idea appealed to the drones. They waved their feelers at Basil, applauding him. "My cry," said Basil, "is Power to the Drones!"

This really made them crazy. Some of them fell over with excitement. (p. 45)

Toute une troupe de faux bourdons, assemblés dans le hall d'entrée, semblait tenir un meeting. C'étaient de sacrés gaillards, et je fus frappé par leurs yeux énormes, qui remplissaient presque toute leur tête. L'un d'entre eux, un peu à l'écart, paraissait tenir un discours. Aussitôt qu'il nous aperçut, il se mit à parler humain, probablement pour faire impression (tout en poursuivant son discours de sémaphore):

- Et je voudrais, messieurs, attirer votre attention sur le fait suivant: nous avons en ce moment, dans notre cité, deux jeunes visiteurs venus du vaste monde. Aussi, je voudrais profiter de leur présence parmi nous pour poser cette question, devant témoins: nos prétendues soeurs, soi-disant ouvrières, oseront-elles nous rejeter hors de la ruche? Commettront-elles ce crime, sous le regard d'étrangers venus du vaste monde, tels ces deux êtres sur le rayon que vous voyez là? Oseront-elles heurter la sensibilité de ces innocents, en nous éjectant au-dehors, dans le dénuement le plus complet, sans aucune ressource, et livrés à la foule de nos ennemis? Oseront-elles nous repousser, dans nos tentatives pour revenir au milieu d'elles, en prétextant qu'elles n'ont ni place ni nourriture pour nous? Non, non, elles ne peuvent pas agir ainsi. Les droits du citoyen existent, je l'ai entendu à la radio, et nous sommes citoyens de la ruche au même titre que les ouvrières, au même titre que la reine elle-même!

Une houle d'antennes tint lieu d'applaudissements.

- Nous n'avons qu'une seule devise, reprit Basile: Les faux bourdons au pouvoir! Cette fois, ce fut du délire. Certains d'entre eux s'en roulaient par terre. (p. 79/80)

This example provides an overview of the tendencies and strategies most prevalent in our corpus. The overall effect of this highly stylized translation is the transformation of the mock pomposity of the English text into a passage espousing Republican citizenship. The translator has used a change in register and discourse to pursue the topic of human rights and citizenship, employing intensified language associated with legal and unionized proceedings. Repetition is a heavily used strategy in both passages, and even though the rhetorical form is used in the original on six occasions (four in French), what is an appeal to moral sense in the English text becomes an exposition of the rights of citizens in French. Stronger terms and intensified language are present in the repetitive use of verbs such as "oser" and "commettre," and in the terms "Les droits du citoyen existent"/“we belong here"; "du vaste monde"/"the outside world"; "énormes"/“large"; "remplissaient”/"took up"; "ces innocents"/"those young eyes"; "Nous n'avons qu'une seule devise"/"my cry"; and the addition of "le fait suivant," "en prétextant," “citoyens," "discours," "titre," “témoins" and "livrer." Transpositions of verbal phrases to nominal phrases occurs with "was meeting"/ "semblait tenir un meeting," and "When we try to return"/“dans nos tentatives pour revenir," and telling is substituted for showing in the translator's summation of the reaction of the bees ("ce fut du délire" / “This really made them crazy”). The generic "à la radio" replaces the culturally specific Australian radio shows "Martin's Corner or Rick the Frontier Scout." As plaintiff rhetoric, the alliteration of successive adjectives in English ("sad, solitary, sopping and starving") is lost in French with the replacement of nouns ("dans le dénuement le plus complet, sans aucune ressource”), but a compensatory allitera- 
tive phrase of a different kind appears later in the French passage ("qu'elles n'ont ni place ni nourriture pour nous. Non, non...").

The grafting strategy - whereby an overlay of discourse-specific language replaces the original - can be seen again in a later passage dealing with the hierarchy of "romantic involvement" between bees in the hive. Mildly present in the original, the discourse of chivalry is grafted onto the translated passage through the combination of formal terms, metaphors and allusions to behavior consistent with heroic men in the legends of the Knights of the Round Table, Camelot and Sleeping Beauty. Totally consistent with euphemistic tendencies already observed in French translations (Frank 2003), the translated passages remove sexual references and marked terms:

“Oh, I don't want to mate with her. I want to be her servant. I want to help guard her. I want to wag my wings and make her hive cool. I want to be her knight."

Nancy giggled behind her hand at the idea of Sir Romeo.

"I'm an expert in the area of knights," said Romeo. "I keep well instructed by listening to the radio. I've heard all about knights and ladies and how the knight was faithful to the lady even if she never let him make love to her." (p. 48)

- Mais je ne demande même pas de me marier avec elle! coupa Roméo. Tout ce que je demande, c'est l'honneur de la servir. De lui tenir lieu de garde de corps. De chevalier servant. L'honneur et la joie d'agiter mes ailes pour la refraîchir, pour ventiler sa ruche. Je ne demande qu'une chose: c'est d'être son prince charmant.

Nancy camoufla un début de fou rire.

- Et je m'y connais, en chevalerie, poursuivit Roméo. Je me suis beaucoup instruit, à écouter la radio. Je n'ignore plus rien en galanterie, je sais tout sur les chevaliers et leurs dames, et comment un chevalier jurait fidélité à sa dame, même si elle ne voulait pas lui accorder sa main...( p. 85/86)

These two examples from Keneally show that constructs and borrowings can come from within French culture as well as from outside, and that the constructs and borrowings are likely to be embedded in discourse-specific language. The next section takes up the theme of French interests in Australia as expressed through preoccupations with Australian specificity.

\section{Australian Specificity versus Acceptability}

The type of retention or deletion of Australian referents in French translations may be more strongly aligned to the translator's concern with the age of intended readership in the target culture rather than to an interest, or lack thereof, in the Australianness of the text. The following examples illustrate the difficulty in determining whether translators have deliberately omitted Australian content or have simply placed greater importance on the acceptability of the text.

A typical example of explicit environmental exposés of Australian flora and fauna is Mary Patchett's Wild Brother (1954) = Frère Sauvage (1955). The book is an interesting example of heavy deletion on the part of the translator, with several pages of many chapters of the source text omitted in translation. The deleted passages have the common features of being Australian, local, "earthy," poetic and environmentally didactic. Many literary and technical passages have been omitted, there is less emotional content, and the hard edge has been taken off the original narrative. 


\section{Mary Patchett. Wild Brother (1954) = Frère Sauvage (1955), Jérôme Harrap (Tr.)}

The Professor poked gentle fun at fellow-scientists of an earlier day who, when platypus was first discovered, decided it was a fake, a creation of the Chinese, who specialised in joining the top half of one animal to the bottom half of another, concealing the join so perfectly that the seam was invisible, then selling it as a Chinese mermaid. The learned men of science took a long time and examined many platypus skins before being convinced that here was a real animal - or perhaps it was a bird for it had webbed feet, or a fish, for it swam? It was a little of all three, and so it became the first of the monotremes. (p. 66)

Le professeur raillait sans méchanceté ses collègues de jadis qui, quand ils virent pour la première fois un platypus, décidèrent que c'était un monstre fabriqué par les Chinois. Les doctes savants durent examiner bien des peaux de platypus avant d'admettre qu'il s'agissait bien d'un animal réel, quoiqu'il ne pût être rangé dans aucune des classifications habituelles. Ces petits reptiles mammifères, couverts de fourrure, qui marchent sur des pattes palmées, nagent comme des poissons, pondent des oeufs, ont une queue semblable à celle des castors et un bec caoutchouteux comme personne, furent cause de bien des discussions entre les naturalistes. Finalement, ceux-ci en firent les premiers des monotrèmes et leur cas fut réglé. (p. 51)

The negative exoticism of the details referring to the joining of the animal may be considered unedifying and inappropriate material for children and are therefore omitted. However, another explanation for the deletion is that this sub-text contains implicit references to the colonial history of Australia, the racial tension in the new colony, and the White Australia Policy. The translation does not respond to the cultural and historical sub-text, but instead becomes overtly didactic and presents a dictionary-like definition of a platypus in response to the questions posed by the author. The translation appears to be written in a friendly style, and includes considerable alliterative effects, but is reflective of didactic discourse in its elaborate description of the platypus. In this example, the retention or omission of didactic passages in translation can be attributed to the difference between information that is local and information that is general. The local is perceived as not so useful or interesting and is therefore deleted while the general is perceived as useful and important and is subsequently retained.

\section{Mary Patchett. Wild Brother (1954) = Frère Sauvage (1955), Jérôme Harrap (Tr.)}

Steve told the Professor of the rivers he had seen dotted with the oblong brown fur patches that are the backs of platypus, and the Professor told Steve about the great naturalist, Linné, the man who first divided living creatures into classes. Platypus and echidna, he told Steve, had the Linnean system stumped, for they were living links with a past so ancient that there were no other creatures like them. Linné died in 1778 and platypus was first seen in 1797, so after argument and opposition a Frenchman called Saint-Hilaire created the order of the monotremes to which these little mammal-reptiles belong. (p. 66)

Translation: Omitted (p. 50)

The omission of this passage from the translation can be explained in simple terms by the suggestion that it is too didactic and therefore boring to children. However, in this passage of utterly Australian discourse, Patchett has chosen to refer to the platypus and echidna, two animals not as well known to French children as kangaroos, koalas and crocodiles. The author has identified these two animals as being as ancient 
as the landscape, and has instructed children about the marked Australianness of these animals in the environment. As such, the deletion of this passage from the translation is not just the deletion of "discours savant," but of Australian cultural icons.

It is not unusual for poetic passages to cause problems for translators, both in the reproduction into another language and also in terms of their perceived interest level for readers. In cases where the translator decides to omit the passages, the fact that they contain Australian content may simply be coincidental. Kookaburras suffer this fate in the following extract:

\section{Mary Patchett. Wild Brother (1954) = Frère Sauvage (1955), Jérôme Harrap (Tr.)}

Kookaburra gives his long, ribald, chuckling laugh, which rises through the stillness of dawn. His great beak is wide open, his big head and round body, even his stumpy tail, shake and quiver with gutsy laughter, for he is the buffoon of the bush, friendly, comical, enchanting. (p. 41)

Translation: Omitted. (p. 29)

Definitely a marked form of Australian specificity and an exotic creature, the kookaburra suffers deletion here and the translator has not reproduced the anthropomorphism so typical of children's fiction. The translator has also deleted another poetic passage where the Australian landscape is presented as a canvas of intentional and unintentional colour. The translator chose not to recreate the canvas, thus whiting out the literary and the cultural content.

\footnotetext{
Mary Patchett. Wild Brother (1954) = Frère Sauvage (1955), Jérôme Harrap (Tr.)

Rain fell onto the desert in patches so that tiny oases, crimson carpets of brilliant Sturt Pea, sprang up as though a giant had shaken drops of red ink from his pen on to vast sheets of brown blotting-paper. (p. 66)

Translation: Omitted. (p. 51)
}

Despite norms and conventions guiding translation acts, translations such as these employ acceptability strategies that do not often subscribe to target constraints of literariness, and therefore result in a softening or simplification of the text. Rather than raising the level of sophistication of the text, the pragmatic forces of translation can compromise literariness and reduce the impact of the poetic energy created from semantic links, images, word play, alliteration, rhyme, and so on. Translators focus on the intended addressees of the translation, and attempt to determine the function fulfilled by the source text in the source culture and its applicability to the target situation. At times the result is a translation that deletes Australian specificity, while on other occasions it leads to a translation that underscores Australianness. Our interest is not only in the choice to attenuate or to heighten Australianness, but also in the type of images portrayed.

\section{Heightened Images of Australia in French Translations}

In translations that are interested in the "otherness" of Australia, we find both literal translations of images from the original works and also images of Australia transmitted to French readers that are not present in the original. In the following example, the child reader of the source text has not yet been told the actual country in which the valley features, but the translator explicitly states the Australian setting. 
Thomas Keneally. Ned Kelly and the City of the Bees $(1978)=$ La cité des abeilles (1981), Rose-Marie Vassallo (Tr.)

When I was a small boy I spent a whole summer with wild honey bees in their nest in the hollow of an old mountain ash [...] I lived in a warm valley then. (p. 9)

Vous me croirez si vous voulez, mais j'ai passé tout un été de mon enfance dans le tronc creux d'un vieux sorbier, chez des abeilles sauvages [...] Nous habitons alors, mes parents et moi, dans une chaude région de l'Australie, au fond d'une vallée tranquille. (p. 7)

The translator situates the valley (specific) within the larger entity of a warm part of Australia (the general "une chaude région"). The translator also adds an explicitation of the genre of the text in the invitational "Vous me croirez si vous voulez," an appeal to the reader to be a participant in la fantaisie. In the following examples, translators have recourse to descriptors other than "chaud" for the concept of heat in order to distinguish warm from hot. When dealing with allusions to the hot Australian climate, such as "burning" or "very warm," the translators exploit the image of Australia as a land of heat in their choice of emphasis on the burning sun.

Thomas Keneally. Ned Kelly and the City of the Bees $(1978)=$ La cité des abeilles (1981), Rose-Marie Vassallo (Tr.)

The wild bees knew how to find a place that was shady and away from the wind. (p. 10)

Les abeilles sauvages, depuis toujours, ont su trouver d'elles-mêmes le meilleur emplacement: un recoin tranquille, à l'ombre du soleil brûlant, à l'abri du vent. (p. 9)

Christopher J. Koch. The Boys in the Island (1958) = Les garçons de l'île (1989), Eléonore Bakhtadzé (Tr.)

Tasmania is an island of hills, a fragment separated from the parent continent by a wide stretch of sea. It is different from the hot Australian mainland; it has a different weather and a different soul, knowing as it does the sharp breath of the south, facing the Antarctic. (p. 8)

La Tasmanie est une île de montagnes, un fragment séparé du continent parent par une large écharpe de mer. Elle diffère beaucoup du continent australien brûlant; par le climat ainsi que par l'esprit, car elle connaît, face à l'Antarctique, l'haleine cinglante du sud. (p. 24)

The translator of Keneally's work has also made explicit what was implicit in the original ("du soleil brûlant" for "shady") and has given in to a mild didactic impulse by adding "depuis toujours" to strengthen the authority of the information. The Koch example represents not only the translation of heat but also the French preoccupation with exotic islands. The legacy of imperialism and the aventurier tradition in French culture are reflected in the large number of selections by French publishers of books set in Tasmania, a place invariably described in translations as a large and unexplored island off the coast of Australia. The specific case of Tasmania brings together the heightened French interest in exploration of the landscape, in exotic animals and people, and in colonial exploitation, and prompts the not entirely unreasonable hypothesis that Tasmania is perceived as France's "lost colony." Further examples display the variety of representations of Australia. 
James Vance Marshall. The Children (1959) = Dans le grand désert (1968), Patrick Reumaux (Tr.)

Far below them, in the bed of the gully, a little stream flowed inland - soon to peter out in the vastness of the Australian desert. (p. 5)

Loin au-dessous d'eux, dans le lit du vallon, un ruisseau s'enfonçait dans les terres avant de se perdre dans les immenses solitudes du désert australien. (p. 9)

Morris Gleitzman. Worry Warts (1991) = Mes parents sont de mauvais poil (1998), Shaïne Cassim (Tr.)

'Being a teacher', he said, 'is like walking across Australia. It's lonely, it's hard going and every day you stub your toe on exactly the same thing... You'd think we teachers'd give up, wouldn't you?' The class nodded. 'But we don't, do you know why?' The class shook their heads. 'Because,' said Mr Gerlach, 'we dream that one day, somewhere in this great land of ours, we'll come across a precious stone.' (p. 32)

«Être professeur, c'est comme marcher dans le désert australien. C'est dur parce que chaque jour, on trébuche sur la même chose... Vous croyez que nous, les enseignants, on abandonne toujours, c'est vrai?» Les élèves hochèrent la tête. «Mais ce n'est pas vrai, vous savez pourquoi?» Les élèves firent «non» en chœur. «Parce que nous rêvons qu'un jour, quelque part dans ce désert sans fin, on trouvera une pierre précieuse». (p. 58/59)

Once again we have images of Australia transmitted to French readers that are not present in the original - "ce désert sans fin" and "immenses solitudes." In the example from Gleitzman, we see Australia metonymically equated simply with desert ("le désert australien"), emphasizing the French preoccupation with desert over urban, rural and coastal settings. The use of the desert image reinforces the elements that go with it, such as sun, heat, drought, sparseness of people and vegetation, and promotes a possible associative function in the mind of the reader of Australia as emptiness or void. The more familiar language "to peter out" in Marshall's work, meaning to eventually come to an end, is given a sense of giving way to something much greater in the use of "se perdre." In the next example from Gleitzman, even qualities pertaining to people are transferred to the landscape in other images.

Morris Gleitzman. Worry Warts (1991) = Mes parents sont de mauvais poil (1998), Shaïne Cassim (Tr.)

[...] he could hitch a lift. And in a friendly country like Australia he'd get one in no time. (p. 50)

Et dans un pays aussi paradisiaque que l'Australie, il allait trouver un aimable conducteur en un rien de temps. (p. 88)

The "friendly" characteristic of the Australian people has been transferred to the landscape as "paradisiaque," presenting an image of Australia once again as landscape over and above all else. In a similar way, the French blurb from a novel by Moorhouse and the blurb and commentaire ${ }^{4}$ for a novel by Winton embellish the Australian referents with descriptors absent from the original texts. 
Frank Moorhouse. Forty-Seventeen (1988) = Quarante dix-sept (1994), Jean-Paul Delamotte (Tr.)

"What could he tell her now that he was forty and she was no longer seventeen? He is a writer turned diplomat, a free spirit painfully learning the value of discipline. He moves in a world which takes him from the Australian bush to the conference rooms of Vienna and Geneva [...]."

«Quarante/dix-sept est le récit du chasse-croisé entre deux êtres. Quarante ans, fonctionnaire international, il n'aime pas les réveillons de Noël en famille. Il préfère aller camper, seul, dans le bush, ce désert australien [...]».

Tim Winton. Dirt Music (2001) = Par dessus le bord du monde (2003), Nadine Gassie (Tr.)

“... Set in the wild landscape of Western Australia [...] It's a journey across landscapes within and without, about the music that sometimes arises from the dust."

«[...] Luther Fox fuit, traverse l'Australie et s'exile sur la côte aride des Kimberley. Georgie, revenue à elle-même, part à sa recherche sur ce bord extrême du monde».

\section{Commentaire}

«C'est pour Georgie le début d'une aventure improbable et dangereuse. Fox s'enfuit en direction du nord de l'Australie occidentale pour accomplir un pèlerinage là où se trouvent les mines d'amiante où son père toute sa vie a trimé. Puis il s'exile volontairement sur la côte aride des Kimberley et rompt définitivement avec le passé. Dans cet univers inhospitalier, grandiose et sauvage, Fox fait l'expérience de la solitude absolue ... La musique du sol raconte l'amour fou entre deux êtres anéantis par les regrets et leur odyssée éblouissante à travers une Australie sensuelle et mythique».

For the Moorhouse example, the translator equates the bush with the Australian desert, presenting an image of the outback as nothing but desert. The translated blurb from Winton transforms the wild landscape of Western Australia into the specific arid Kimberley region and defines it as "the extreme edge of the world" (my emphasis). What is interesting about the Winton example is that the translator of the commentaire not only adds a large quantity of referents, but also represents Australia as a land of adventure and danger, as inhospitable and wild, a place that engenders feelings of isolation, and yet a mythical and sensual place. The image of Australia as the exotic and distant "other" also appears in the translations of Tasmania in a passage from Baillie and in the blurb from Chauncy. Both the landscape and exotic fauna receive particular attention in translations that reflect heightened images of an Australia that is mysterious, unexplored and unmapped - essentially, a cartographer's perpetual delight. As observed by Pons (2000) and MacDonald (1996), this set of images reinforces the fascination Australia holds for the European consciousness.

\footnotetext{
Allan Baillie. Riverman (1986) = Périls en Tasmanie (1994), Smahann Joliet (Tr.)

Dad told Brian that Great Uncle Tim had been a pioneer in the wild west of Tasmania when there were no roads and great areas of the map were blank. (p. 9)

Le père de Brian avait appris à son fils que le grand-oncle Tim avait été un pionnier de l'ouest de la sauvage Tasmanie. A l'époque, les routes n'existaient pas et de grandes zones sur les cartes demeuraient totalement inexplorées et mystérieuses. (p. 8)
} 
Nan Chauncy. Tiger in the Bush (1957) = Le vallon secret (1961), Edith Vincent, (Tr.)

"For eleven-year old Badge, the world is bounded by the high ridges that enclose his valley home, deep in the heart of Tasmania. He delights in the wildlife that surrounds him, and cares little for the world Outside... He had once been shown one of the country's rarest animals, the nearly extinct Tasmanian tiger, ... [he] will want to carry the rare animal away from the free life of the wilds into captivity.

Against a wonderfully vivid portrayal of the Tasmanian bush, Chauncy has set a compelling story..."

«Dans la grande île de Tasmanie se trouvent encore des terres ignores 'en dehors de la carte,' où vivent seuls quelques fermiers entreprenants, et des animaux que l'on ne trouve nulle part ailleurs. Le jeune Womb, garçon de dix ans, en sait plus long sur les bêtes sauvages de son pays que les plus doctes savants... Il ne craindra pas de prendre de gros risques pour protéger ... la vie d'un des derniers 'Tigre' de Tasmanie».

The exotic other is also present in referents to indigenous inhabitants and their "primitive" ways, as shown in the French representation of Aboriginal Australians in the Northern Territory.

Mrs Aeneas Gunn. The Little Black Princess of the Never-Never (1962) = Bett-Bett petite princesse australienne (1990), Paquerette Feissel (Tr.)

"Made from simple sketches of Northern Territory life and centred round little black Bett Bett, who took refuge with Mrs. Aeneas Gunn (author of "We of the Never Never"), The Little Black Princess of the Never Never is a recognized Australian classic and has delighted readers for years. It is a particular favourite with children. Bett Bett appears, stays awhile, learns a little, and finally goes bush again."

«Cette histoire véridique se situe en 1902 dans le Never-Never, région tropicale de l'extrême Nord du continent australien. La destinée de Bett-Bett, petite Aborigène de huit ans, est toute tracée: elle sera la reine de sa tribu. Ainsi en ont décidé, à sa naissance, les Anciens ... Mrs Aeneas Gunn (née à Melbourne, 1870-1961), est la première femme blanche à oser affronter les dures conditions de vie de cette région d'Australie encore inexplorée. Elle vivait à Else-Station, le domaine où des pionniers faisaient l'élevage de bovidés. Elle a su gagner la confiance des Aborigènes et explique avec respect leur mode de vie et leurs rites et coutumes».

In the Baillie example, the "wild" aspect of the western part of Tasmania has been transferred to the entire island in the phrase "de l'ouest de la sauvage Tasmanie." True to the French "aventurier" tradition, the blank areas of the map become "unexplored and mysterious zones" in translation. The French preoccupation with indigenous populations of exotic lands is evident in the French blurb from Gunn, where the socio-cultural specificity is considerably enhanced in the translation. For a book concerned with the depiction of Aboriginal culture, the original blurb fails to mention the word "Aboriginal." The translator of the French blurb reflects a greater sensitivity to Australian history, geography and race in what is clearly a free interpretation of the original blurb. The colonial exploitation of Algeria by France is a sure reminder to French translators of the negative aspects of colonial imperialism, exerting a profound influence on their degree of sensitivity to matters of race and rights. Riemer (2003) notes such sensitivity in his discussion of the translation of a novel for adults concerning the plight of the last Tasmanian Aboriginals, ${ }^{5}$ and several translations from the present corpus show a greater degree of accuracy in the portrayal of indigenous Australians than the original works. 
The association of Australia with the wild, harsh, natural environment is poignantly illustrated in the final example of the blurbs from a family story set in Central Australia. As a book that is designed to appeal more to girls than to boys, the translation shows consensus of readership in its designation as part of the Collection "Monique" produced specifically for girls. The translation succeeds in embellishing the Australian referents both in number and in kind.

\section{Phyllis Power. Under Australian Skies (1955) = Sept filles dans la brousse (1958), Alain Valière $(\mathrm{Tr}$.)}

"Life on a cattle station in the vast, lonely stretches of Central Australia is the background of this unusual story. At Wander Nella, over three hundred miles from the nearest township, live the Clarkes, mother, father and seven daughters. Remote their home may be, but life is far from dull with dozens of interests - the aborigines whose camp is close to the homestead, cattle and horses to be mustered, swimming, camping and so on. A real excitement occurs when important visitors arrive and Ivor joins the family on the station. Further thrills ensue with the coming of the mailman, an exploring trip into untravelled country, and the siege of the homestead by hostile natives incited by a renegade police boy and an unpleasant medicine-man. All ends well, and the reader can well believe that there are no happier girls in the world than those seven at Wander Nella."

«Aux enfants de France à qui cette lointaine Australie - île mystérieuse, vaste comme un continent - est si peu familière... Là, à des centaines de milles de toute côte, vivent encore des tribus primitives, adonnées à des rites étranges qui ont traversé les siècles. Le missionaire - catholique ou protestant - ne les visite qu'à de rares intervalles. Là, vivent aussi les animaux les plus étonnants du monde. Par la magie du livre qui nous transporte à l'autre bout de la terre plus vite que ne le ferait le plus rapide des longscourriers, avec Marion, Sally, Olga, Olive, Nancy, Betty, Alice, nous allons connaître l'aventure exaltante des colons de la brousse australienne».

This stylistically embellished French extract embodies a succession of French preoccupations with Australia that go well beyond the chronology of local detail in the original text. The French translation constructs Australia as a vast, mysterious and isolated place far removed from the European centre, an outback colony teeming with exotic animals and indigenous tribes, a wild place in need of civilizing influences and, above all, a source of constant adventure. The very fact that these publications date from almost half a century ago prompts an attempt to defend the set of traditional images of Australia presented in the translation as historically naive. However, the examples analyzed in this study from more recent years confirm this set of images as consistent and current even at the end of the twentieth century.

\section{Conclusion}

This study has identified some of the forces and constraints operating in the selection and translation of Australian fiction into French. Translation as reading and interpretation means that a translated text can be justifiably different in some sense from the original. The sheer number of translational changes in the corpus reflects a considerable variety of translational tendencies and interpretive choices at work, and provides evidence of the difficulties in moving texts from one culture to another. While many translational changes, such as explicitation and attenuation, are simply pragmatic and universal choices by translators who are focused on their readers, French translations 
of Australian referents also project a consistent set of traditional, conservative and limited images of the land and its culture. Emphasis on aspects of Australia in the translations consistently goes beyond strategies designed to hold the reader's attention, and reveals specific constructs of Australian culture and geography that result from historical and residual French interests in foreign lands. Translating regional Australia effectively correlates with slanting the text to culture-specific suppositions about Australia.

The set of images most evident in French translations of the foreignness of Australia reveals Australia as the antipodes, as an exotic and wild place where anything can happen, as the end of the world, and - somewhat paradoxically - as a paradise, with Edenic images. While Pons (2000) has argued for a French perception of Australia as a sophisticated nation, there is sufficient evidence in the literary texts examined in this study to suggest that the predominant French notions of l'Australie through fiction remain synonymous with "dépaysement et d'aventure." Consequently, Australia's seemingly exotic, wild and distant status in French eyes confirms that a deeper understanding of Australian national cultural identity through fiction invites further exploration.

\section{NOTES}

1. Pons teaches at the Université de Toulouse-Le Mirail. He is a member of editorial advisory committees for the study of Australian literature, and was president of the European Association for the Study of Australia (EASA) from 1997-1999.

2. The use of bolding within the examples represents personal use; italics in the original texts and translations are retained.

3. For a comprehensive listing of French fiction set in colonial Australia, see Clancy, P.A. \& C.B. Thornton-Smith. Analytical Checklist of French Fiction and Pseudo-memoirs Set in Colonial Australia. Melbourne: Institute for the Study of French-Australian Relations, and The Australian Centre, The University of Melbourne, 1991.

4. The commentaire is reproduced from the website http://www.alapage.com (consulted 13/01/04).

5. Riemer discusses his English translation of L'enfant du people ancien (Paris: Fayard-Pauvert, 2000) by the Franco-Algerian novelist Anouar Benmalek. The novel is set in Algeria, France, Tasmania and Victoria.

\section{REFERENCES}

Aldous, A. (1945): McGowan Goes to Sea, London, Oxford University Press. / (1951): MacGowan dans les mers du sud, Paris, B. Arthaud.

Aldridge, J. (1986): The True Story of Spit MacPhee, London, Viking. / (1988): La véritable histoire de Spit MacPhee, Paris, Hachette/Stock.

Baillie, A. (1986): Riverman, London, Blackie. / (1994): Périls en Tasmanie, Paris, Castor Poche Flammarion.

Bartolini, P. (2003): “On Translating,” Southerly 63-1, p. 83-92.

Betts, R. (1978): Tricouleur: The French Overseas Empire, London, Gordon and Cremonesi.

Brinsmead, H. (1979): Once There Was a Swagman, Melbourne, Oxford University Press. / (1986): Un jour, un vagabond, Paris, Castor Poche Flammarion.

Carey, P. (2000): True History of the Kelly Gang, St Lucia, University of Queensland Press. / (2003): Véritable Histoire du Gang Kelly, Paris, Plon.

Chauncy, N. (1957): Tiger in the Bush, London, Oxford University Press. / (1961): Le vallon secret, Paris, Éditions de l'Amitié - G.-T. Rageot.

Chauncy, N. (1963): The Roaring 40, London, Oxford University Press. / (1968): La côte des naufragés, Paris, Éditions de l'Amitié - G.-T. Rageot. 
Dann, M. (1982): Adventures with My Worst Best Friend, Melbourne, Oxford University Press. / (1987): Mon meilleur ennemi, Toulouse, Milan.

Fennimore, S. (1948): Bush Holiday, London, William Heinemann. / (1957): Vacances en Australie, Paris, Éditions de l'Amitié - G.-T. Rageot.

Frank, H. T. (2003) (unpub.): Pre-empting the Text: French Translations of Twentieth Century Australian Children's Fiction, Ph.D. Thesis, Melbourne, Department of French and Italian Studies, The University of Melbourne.

Franklin, M. (1928): Up the Country, Sydney, ETT Imprint. / (1996): Le pays d'en haut, Paris, Éditions de l'aube.

Gleitzman, M. (1991): Worry Warts, London, Penguin. / (1998): Mes parents sont de mauvais poil, Paris, Hachette Jeunesse.

Gleitzman, M. (1993): Sticky Beak, London, Penguin. / (1998): Le bébé de papa compte plus que moi, Paris, Hachette Jeunesse.

Gunn, J. (Mrs Aeneas) (1962 [1905]): The Little Black Princess of the Never-Never, Sydney, Angus and Robertson. / (1990): Bett-Bett petite princesse australienne, Paris, Magnard.

Hunt, S. and P. Carter (1999): Terre Napoléon: Australia Through French Eyes 1800-1804, Sydney, Historic Houses Trust of New South Wales in association with Hordern House.

JACKson, J. H. (2003): Making Jazz French: Music and Modern Life in Interwar Paris, Durham, Duke University Press.

Keneally, T. (1978): Ned Kelly and the City of the Bees, London, Jonathan Cape. / (1981): La cité des abeilles, Paris, Castor Poche Flammarion.

Косн, С. (1958): The Boys in the Island, London, Hamish Hamilton. / (1989): Les garçons de l'île, Paris, L'École des Loisirs.

Macdonald, A. (1996): "French Film-Critic Takes a Holiday: Les Cahiers Do Desert-Island Discourse," in Warren, J., Nettelbeck, C. and W. Kirsop (eds): A Century of Cinema: Australian and French Connections, Melbourne: Department of French and Italian Studies, The University of Melbourne.

Marshall, J. V. (1959): The Children, London, Michael Joseph. / (1968): Dans le grand désert, Paris, Gallimard.

McGregor, A. (2004): "French film criticism and cultural hegemony: The perpetual French 'discovery' of Le Cinéma des Antipodes," French Cultural Studies 15-2, p. 158-173.

Monaghan, P. (2003): "Wild frontier legend refuses to ride into the sunset," The Australian 8, p. 26-27.

Moorhouse, F. (1988): Forty Seventeen, London, Faber. / (1994 [1992]): Quarante dix-sept, Paris, Rivages.

Nettelbeck, C. (2004): Dancing with de Beauvoir: Jazz and the French, Carlton, Melbourne University Press.

Oittinen, R. (2000): Translating for Children, New York, Garland.

Osborne, M. A. (1994): Nature, the Exotic, and the Science of French Colonialism, Bloomington, Indiana University Press.

Patchett, M. E. (1954): Wild Brother, London, Collins. / (1955): Frère sauvage, Paris, Robert Laffont.

Patchett, M. E. (1962): In a Wilderness, London, Hodder and Stoughton. / (1965): Mirri chien sauvage, Paris, Calmann-Lévy.

Pons, X. (2000): L'Australie, entre Occident et Orient, Paris, La Documentation Française.

Power, P. M. (1955): Under Australian Skies, London, Blackie and Son. / (1958): Sept filles dans la brousse, Paris, Fleurus.

Prochaska, D. (1990): Making Algeria French: Colonialism in Bône, 1870-1920, Cambridge, Cambridge University Press.

Riemer, A. (2003): "Language, culture and the perils of translation," Southerly 63-1, p. 51-61.

Southald, I. (1953): Simon Black in Coastal Command. Sydney, Angus and Robertson. / (1954): Allô contrôle, ici radar!, Paris, Les Presses de la Cité. 
Thiele, C. (1985): River Murray Mary, Adelaide, Rigby. / (1985): Mary, la rivière et le serpent, Paris, Castor Poche Flammarion.

Toury, G. (1995): Descriptive Translation Studies and Beyond, Amsterdam, Benjamins.

Ward, R. (1958): The Australian Legend, Melbourne, Oxford University Press.

Winton, T. (2001): Dirt Music, St Lucia, University of Queensland Press. / (2003): Par dessus le bord du monde, Paris, Rivages. 